\title{
Expression of leukosialin (CD43) defines a major intrahepatic T cell subset associated with protective responses in visceral leishmaniasis
}

\author{
Dirlei Nico ${ }^{1}$, Naiara Maran², Leonardo Santos ${ }^{2}$, Erivan Schnaider Ramos-Junior ${ }^{3}$, Natália Rodrigues Mantuano ${ }^{3}$, \\ Joseane Lima Prado Coutinho ${ }^{3}$, Andre Macedo Vale ${ }^{3}$, Celio Geraldo Freire-de-Lima ${ }^{3}$, Adriane Todeschini ${ }^{3}$, \\ Juliany Cola Fernandes Rodrigues ${ }^{3}$, Clarisa Beatriz Palatnik-de-Sousa ${ }^{1}$ and Alexandre Morrot ${ }^{2^{*}}$
}

\begin{abstract}
Background: Leishmaniasis is a neglected vector-borne tropical disease caused by Leishmania protozoa that are transmitted to mammalian hosts by infected sand flies. Infection is associated with distinct clinical manifestations that include cutaneous, mucocutaneous and visceral lesions. Visceral leishmaniasis $(\mathrm{VL})$ is the most severe form of the disease and is considered second in terms of mortality and fourth in terms of morbidity among tropical diseases. IFN- - -producing $T$ cells are involved in protection against the disease.
\end{abstract}

Methods: $\mathrm{CD}_{4} 3^{+/+}$and $\mathrm{CD} 43^{-/-}$mice on a C57BL/6 background were intravenously injected with $5 \times 10^{7}$ amastigotes of Leishmania (L.) infantum chagasi, and 30 days after infection the clinical signs of disease were examined; the splenocytes were isolated and assayed for cytokine production; and the livers were removed for phenotypic analysis of T cell subsets by flow cytometry.

Results: We report that mice lacking CD43 display increased susceptibility to infection by Leishmania (L.) infantum chagasi, with higher parasite burdens than wild-type mice. The increased susceptibility of $\mathrm{CD}_{4} 3^{-1-}$ mice were associated with a weakened delayed hypersensitivity response and reduced levels of lgG2a antibodies to leishmania antigens. We further showed that expression of CD43 defines a major intrahepatic CD4 ${ }^{+}$and $C D 8^{+} T$ cell subsets with pro-inflammatory phenotypes and leads to increased levels of IFN- $\gamma$ secretion by activated splenocytes.

Conclusions: Our findings point to a role of CD43 in the development of host resistance to visceral leishmaniasis.

Keywords: Visceral leishmaniasis, Leishmania (L.) infantum chagasi, Leukosialin (CD43), Intrahepatic T cell subsets, Host protective responses

\section{Background}

Infection with leishmania spps can induce diseases varying from local cutaneous lesions to systemic visceral manifestations. Parasites of the intracellular protozoan, Leishmania, are transmitted to mammalian hosts by sand fly vectors. The parasites have a dimorphic life cycle consisting of extracellular promastigotes in the vector, and intracellular amastigotes inside mammalian macrophages [1]. The different pathologies are associated with different degrees of

\footnotetext{
* Correspondence: morrot@micro.ufrj.br

${ }^{2}$ Departamento de Imunologia, Instituto de Microbiologia, Universidade Federal do Rio de Janeiro (UFRJ), CCS - Sala D1-035, Av. Carlos Chagas Filho, 373 - Cidade Universitária, CEP 21.941-902, Ilha do Fundão, Rio de Janeiro, RJ, Brazil

Full list of author information is available at the end of the article
}

parasite spread. Parasite species such as L. major are confined to cutaneous lesions while others such as $L$. donovani and Leishmania (L.) infantum chagasi have the capability to disseminate into visceral organs such as spleen and liver, and bone marrow causing visceral leishmaniasis, the most severe form of the disease [2]

Adaptive immunity against leishmaniasis is associated with development of $\mathrm{T}$ cell-mediated interferon-gamma $(\mathrm{IFN}-\gamma)$ responses. IFN- $\gamma$ secreted by $\mathrm{CD} 4^{+}$and $\mathrm{CD} 8^{+} \mathrm{T}$ cells mediates the respiratory burst in activated macrophages which is responsible for the production of nitric oxide needed for parasite killing inside reservoir cells $[3,4]$. Other cytokines can modulate the anti-parasite activity promoted by IFN- $\gamma$. It has been demonstrated that 
IL-12 is able to promote Th1 cell-associated mechanisms by inducing IFN- $\gamma$, which activates macrophages to kill intracellular parasites in granulomas formed in parasitized tissue foci $[5,6]$. While it has been shown that TNF- $\alpha$ is able to enhance the macrophage leishmanicidal activity induced by IFN- $\gamma$, increased levels of IL-10 oppose macrophage activation by blocking Th1 cellular responses [4,7].

Other host determinants are associated to subclinical and symptomatic infections by leishmania species. In the visceral form of the disease, Nramp1 (natural resistanceassociated macrophage protein one) induces inflammatory responses that limit proliferation of the intracellular pathogen in macrophage reservoirs [8]. Other cytokines such as IL-4 $[9,10]$ and TGF- $\beta[11]$ are associated with increased host susceptibility to the infection. In humans, polymorphism for CXCR2 as well as for Notch 3 Deltalike 1 ligand, which drives CD4 T helper 1 cell responses, contributes to susceptibility to visceral leishmaniasis and affects the outcome of the disease $[12,13]$.

Studies of the key gene products controlling infection are important for developing interventions aimed at stimulating Th1-type responses and enhancing resistance to leishmania infection. Optimal activation of anti-leishmanial Th1 responses requires costimulatory signals triggered by the interaction of surface molecules on T cells and antigenpresenting cells. The activation of signal-transducing receptor pathways promoted by the interaction between CD40 ligand-CD40 and CD28-B7 in immunological synapses can stimulate Th1 type responses and enhance resistance to various forms of experimental leishmaniasis [14].

In the present study we investigated the role of a third class of costimulatory receptors represented by CD43 (leukosialin), which is involved in the induction of Th1 responses in other models such as autoimmune encephalomyelitis [15] and diabetes [16]. CD43 is a large sialoglycoprotein highly expressed by $\mathrm{T}$ cells; it is abundant on the $\mathrm{T}$ cell surface, and interacts with the $\mathrm{T}$ cell receptor to initiate signaling events during T cell priming [17]. CD43 signals potentiate the expression of IFN- $\gamma$ by $\mathrm{T}$ cells during TcR activation of naive cells, and the CD43 signaling pathway induces the expression of IFN- $\gamma$ by effector $\mathrm{CD}^{+} \mathrm{T}$ cells and to a lesser extent $\mathrm{CD}^{+} \mathrm{T}$ cells [18].

Synergism between the CD43 and TcR signaling pathways promotes increased transcription of T-bet genes in $\mathrm{CD}^{+} \mathrm{T}$ cells and inhibits the transcription of GATA-3 genes in both $\mathrm{CD}^{+}$and $\mathrm{CD}^{+} \mathrm{T}$ cells, a commitment profile characteristic of IFN- $\gamma$-producing type $1 \mathrm{~T}$ cells [18]. Beside its dynamic role in progression of the $T$ cell differentiation program, CD43 plays a positive role in $\mathrm{T}$ cell homing from lymphoid organs to peripheral tissues $[16,19,20]$. In the experimental meningitis model induced by lymphocytic choriomeningitis virus (LCMV), infection of $\mathrm{CD} 43^{-/-}$mice led to increased morbidity associated with decreased trafficking of virus-specific
$\mathrm{CD}^{+}{ }^{+} \mathrm{T}$ cells to tissues such as the brain [21]. Other studies using anti-CD43 antibody to block T cell migration to pancreatic islets in non-obese diabetic mice have highlighted the role of CD43 in the costimulation and trafficking of $\mathrm{T}$ cells, which can prevent autoimmune diseases such as insulin-dependent diabetes mellitus [16].

Given the positive regulatory role of CD43 in the induction of IFN- $\gamma$-dependent $\mathrm{T}$ cell responses and the homing properties of $\mathrm{T}$ cells to peripheral non-lymphoid organs where most interactions with pathogens take place, we sought to characterize the importance of CD43 in an experimental model of visceral leishmaniasis. In this study we evaluated the potential role of CD43 in visceral leishmaniasis using C57BL/6 wild type mice and CD43 knock-out derivatives $\left(\mathrm{CD}_{4} 3^{-/-}\right)$on the same C57BL/6 genetic background.

\section{Methods}

\section{Ethics statement}

All mouse studies followed the guidelines set by the National Institutes of Health, USA. The study was approved by the Research Ethics Committee of Federal University of Rio de Janeiro, (protocol IMPPG040-07/16). Protocols for animal were approved by the Institutional Ethical Committees in accordance with international guidelines. All animal experimentation was performed in accordance with the terms of the Brazilian guidelines for animal welfare regulations.

\section{Animals and infection}

C57BL/6 wild type control mice and C57BL/6 CD43-/knock-out $\left(\mathrm{CD} 43^{-/-}\right)$originated from breeding colonies kindly donated by Professor Anne Sperling (University of Chicago, USA) were maintained in our animal facilities (UFRJ). Experimental infection was performed by inoculating 4-8 week-old female $\mathrm{C} 57 \mathrm{BL} / 6 \mathrm{CD} 43^{+/+}$and $\mathrm{CD} 43^{-1-}$ mice intravenously with $5 \times 10^{7}$ Leishmania (L.) infantum chagasi amastigotes (IOC-L 3324) obtained from infected hamster spleens.

\section{Intrahepatic parasite load and delayed-type hypersensitivity (DTH) assay}

Thirty days after infection, mice were euthanized and the liver parasite load was evaluated in Giemsa-stained smears and expressed in LDU values (Leishman Donovan units of Stauber $=$ number of amastigotes per 1000 liver cell nuclei/ mg of liver weight). The DTH against L. (L.) donovani lysate was measured in the footpads at 28 days postinfection by intradermally injection in the right front footpad with $10^{7}$ freeze-thawed stationary phase Leishmania (L.) infantum chagasi (L579 Fiocruz) promastigotes in 100 $\mu \mathrm{l}$ sterile saline solution. Footpad thicknesses were measured as described at 0,24 and $48 \mathrm{~h}$ after injection, and the values of the saline control in the contra-lateral 
footpad were subtracted from the reaction against the Leishmania antigen.

\section{Flow cytometry}

For $\mathrm{T}$ cell phenotyping experiments, spleens were removed from infected and control animals. The organs were minced, washed and resuspended in PBS-FCS 5\% for subsequent evaluation of cellularity, which was followed by triple or quadruple immunofluorescence staining. Cells were then fixed and analyzed by flow cytometry in a FACSCalibur flow cytometer. Analyses were done after recording 25,000-50,000 events for each sample, using a CELLQuest software (Becton Dickinson). Lymphocytes were gated based on forward and side scatter parameters, so as to avoid larger leukocytes such as macrophages and granulocytes. For determination of the cytokine mRNA transcripts expressed on $\mathrm{T}$ cells, $\mathrm{CD}^{+}{ }^{+}$and $\mathrm{CD}^{+} \mathrm{T}$ cell subsets was obtained based on the expression of the CD43 marker by FACS cell sorting using anti CD3-APC, anti CD4-PERCP, anti CD8-PE and anti-CD43-FITC. After FACS cell sorting, the total RNA from isolated $\mathrm{T}$ cells was extracted using TRIzol (Invitrogen, Life Technologies) and reverse-transcribed to cDNA with SuperScript TM III Reverse Transcriptase (Invitrogen, Life Technologies).

\section{Quantification of mouse cytokine mRNA transcripts}

Real-time PCR was performed with the ABI Prism 7900HT Fast Real-Time PCR System instrument (Applied Biosystems) using the qPCR SYBR Green Core Kit (Eurogentec) according to the manufacturer's instructions. The amplification program included an initial denaturation step at $95^{\circ} \mathrm{C}$ for $10 \mathrm{~min}$, followed by denaturation at $95^{\circ} \mathrm{C}$ for $15 \mathrm{~s}$, and annealing and extension at $60^{\circ} \mathrm{C}$ for $1 \mathrm{~min}$, for $45 \mathrm{cy}-$ cles. SYBR Primers used to amplify specific gene products from murine cDNA were IFN- $\gamma$ sense, $5^{\prime}$-cggcacagtcatt gaaagcc-3'; IFN- $\gamma$ antisense, $5^{\prime}$-tgtcaccatccttttgccagt-3'; TNF- $\alpha$ sense, $5^{\prime}$-ttctatggccagaccctca-3'; TNF- $\alpha$ antisense, $5^{\prime}$-gtggtttgctacgacgtggg- $3^{\prime}$; TGF- $\beta$ sense, $5^{\prime}$-accgcaacaacgc catctat-3'; TGF- $\beta$ antisense, $5^{\prime}$-tgcttcccgaatgtctgacg-3'; IL17 sense, 5' - tctttaactcccttggcgca-3'; IL-17 antisense, 5' ttcattgcggtggagagtcc-3'; IL-10 sense, $5^{\prime}$-tgaattccctgggtga gaagc-3'; IL-10 antisense, 5'-acaggggagaaatcgatgacag-3'; GAPDH sense, 5'-tgcaccaccaactgcttagc-3'; GAPDH antisense, $5^{\prime}$ '-ggcatggactgtggtcatgag-3'. Green fluorescence was measured after each extension step, and the specificity of amplification was evaluated by melting curve analysis. The relative gene expression levels were calculated using the comparative Ct method (according to Applied Biosystems), where $C t$ represents the threshold cycle. Every sample was run in three parallel reactions.

\section{Anti-Leishmania (L.) infantum chagasi ELISA}

Isotype specific serum antibody responses were monitored by an enzyme-linked immunosorbent assay (ELISA) using the freeze and thawed lysate of stationary phase promastigotes of Leishmania (L.) infantum chagasi (L579 Fiocruz) as antigen. Whole parasite antigens were diluted to $2 \mu \mathrm{g} / \mathrm{ml}$ in PBS buffer (pH 7.0), and separately added at $100 \mu \mathrm{l} /$ well to 96 well plate. After overnight incubation at $4^{\circ} \mathrm{C}$, the plates were washed three times using PBS containing 0.05\% (vol/vol) Tween 20 (Sigma, Gillingham, UK). Serial twofold 1:100 to 1:800 dilutions of serum samples obtained from infected mice at 30 days post-infection (DPI) and normal mice as control diluted in PBS containing $0.05 \%$ Tween were added to the plates and incubated at $37^{\circ} \mathrm{C}$ for $1 \mathrm{hr}$. Following three washes with PBS containing $0.05 \%$ Tween, 1:5,000 dilution of peroxidaselabelled each goat anti-mouse Ig isotypes (IgG1,IgG2a and IgG2b) (Jackson ImmunoResearch, West Grove, USA) prepared in PBS containing $0.05 \%$ Tween was added at $100 \mu \mathrm{l} /$ well and the plates incubated at $37^{\circ} \mathrm{C}$ for $1 \mathrm{hr}$. Following six washes with PBS containing 0.05\% Tween, the reaction was developed with $50 \mathrm{mM}$ phosphate/citrate buffer ( $\mathrm{pH}$ 5.0) containing $2 \mathrm{mM}$ o-phenylenediamine $\mathrm{HCl}$ and $0.007 \%$ (vol/vol) $\mathrm{H}_{2} \mathrm{O}_{2}$ (Sigma, UK), and interrupted with the addition of $2 \mathrm{M} \mathrm{H}_{2} \mathrm{SO}_{4}(50 \mu \mathrm{l} /$ well). The ELISA plates were read at $490 \mathrm{~nm}$ (Spectra Max 190, Molecular Devices, Sunnyvale, USA).

\section{T Cell activation and Cytokine assays}

For restimulation assay, splenocytes $\left(1 \times 10^{6} / 0,5 \mathrm{~mL}\right)$ obtained from control or infected mice at day 30 DPI were cultured in 48 well at $37^{\circ} \mathrm{C}$ and $5 \% \mathrm{CO} 2$ in complete RPMI medium, in the presence or not of $10^{6}$ freeze-thawed stationary phase Leishmania (L.) infantum chagasi (L579 Fiocruz) promastigotes. After 3 days of in vitro stimulation, supernatants were collected and cytokine levels (IFN- $\gamma$, TNF- $\alpha$, IL-10 and TGF- $\beta$ ) were assayed by ELISA utilizing purified and biotinylated Abs (R\&D Systems), biotin-conjugated streptavidin-alkaline phosphatase (BD Pharminge) and developed with ELISA Develpment Kit from R\&D System according to the manufacturer's instructions. Plates were read at $405 \mathrm{~nm}$ and values are presented as pg cytokine/mL (mean $\pm \mathrm{SE}$ ).

\section{Statistical analysis}

Statistical analyses were performed with GraphPad Prism 4 software, using one-way ANOVA and Turkey test. Results were expressed as mean \pm standard error (S.E.), Differences between control and treated group were considered statistically significant when $P \leq 0.05$.

\section{Results}

Expression of leukosialin (CD43) is critical for resistance to visceral leishmaniasis

Visceral leishmaniasis is characterized by multiple organ infections that promote systemic immune responses. At the outset of infection the liver contains infected tissues 
constituting important reservoirs of parasites that are the target of anti-leishmania $\mathrm{T}$ cell protective immune responses [22]. We examined the relevance of CD43mediated IFN- $\gamma$ responses in antileishmanial immunity, and their role in inhibiting intrahepatic development of the parasite. To this end, we used a murine model of $\mathrm{VL}$ in which infection of C57BL/6 mice with Leishmania (L.) infantum chagasi amastigotes gives rise to a higher parasite load in the liver than in other organs such as the spleen and bone marrow during the first weeks, after which it is controlled by the host immune response.

We observed a lower DTH response to the promastigote leishmania antigen in $\mathrm{CD} 43^{-1-}$ mice on a $\mathrm{C} 57 \mathrm{BL} / 6$ background than in wild type C57BL/6 mice after infection with Leishmania (L.) infantum chagasi (Figure 1A). These data indicate that cellular immunity against visceral infection of leishmania parasite is impaired in knockout mice, raising the possibility that CD43 is required for optimal development of host resistance to VL. We next examined the signs of acute infection in the liver. Following intravenous infection with amastigote forms of Leishmania (L.) infantum chagasi we observed that the increased susceptibility of CD43-deficient mice was correlated with greater increases in the liver/body weight ratio (Figure 1B) and intrahepatic parasite burden at 30 days post-infection in $\mathrm{CD} 43^{-/-}$mice than in the wild-type control mice (Figure 1C).

The increased susceptibility of CD43-deficient mice infected with Leishmania (L.) infantum chagasi is associated with a switch in the humoral response and diminished levels of IFN- $\gamma$

Resistance to visceral infection by Leishmania species is associated with the IgG isotype profile [23]. Hence, we measured specific IgG antibody levels in mouse serum to determine whether the impaired resistance of CD43deficient mice is associated with a switch in the IgG subtype profile. Serum samples were collected at day 30 post-infection and IgG titers were determined by ELISA. We found that levels of IgG2a parasite-specific antibodies in infected $\mathrm{CD} 43^{-/-}$mice were significantly lower than in infected wild-type mice (Figure 2). On the other hand, the IgG1 and IgG2b antibodies themselves, from both groups, did not differ significantly in their reactivity to lysates (Figure 2).
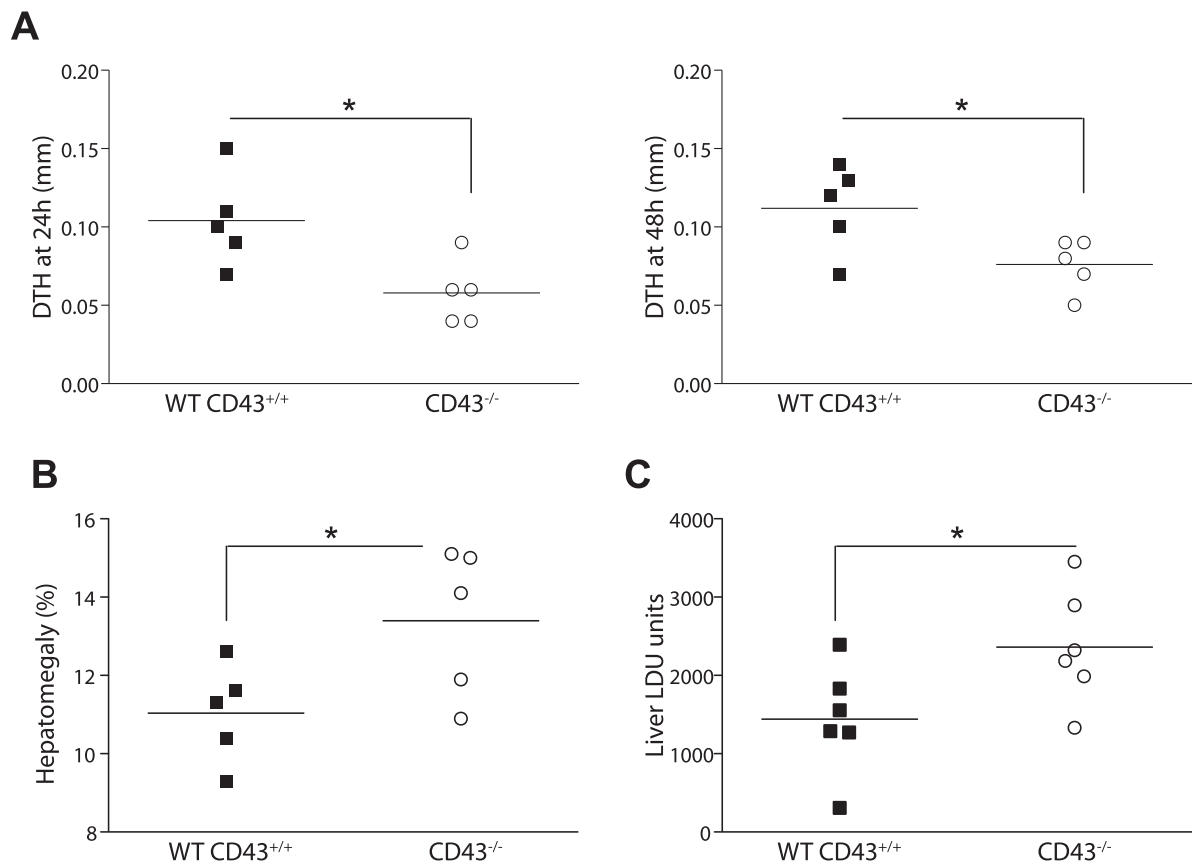

C

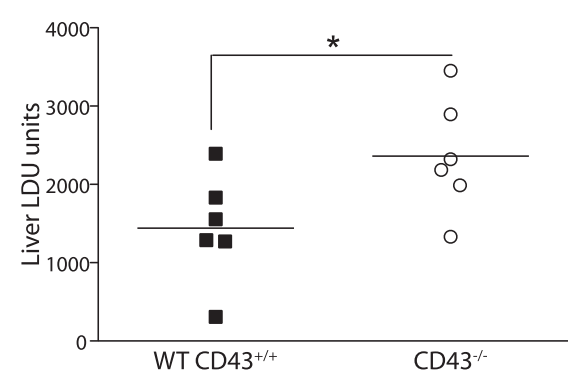

Figure 1 CD43 deficient mice are susceptible to visceral leishmaniasis. $\mathrm{CD} 43^{+/+}$and $\mathrm{CD} 43^{-/-}$mice on a C57BL/6 background were intravenously injected with $5 \times 10^{7}$ amastigotes of Leishmania (L.) infantum chagasi, and 30 days after infection the clinical signs of disease were examined. (A) Infection in CD43-deficient mice results in an impaired DTH response. The vertical axis in the histogram represents the individual values of the thickness of the skin reaction in $\mathrm{mm} 24 \mathrm{~h}$ and $48 \mathrm{~h}$ after intradermal injection of $10^{7}$ freeze-thawed stationary phase promastigotes at $30 \mathrm{DPI}$. Controls with saline were done by contra-lateral injection and their values were subtracted from the reaction promoted by Leishmania antigen. (B) Liver/body relative weights are increased in infected CD43-deficient mice. The body weight was measured in grams at day 30 and the liver/body relative weights (grams of organ weight $\times 100$ / grams of body weight) were determined in CD43 $3^{+/+}$and CD $43^{-/-}$mice. (C) Increased parasite burden in the liver of CD43-deficient mice. The vertical axis in the histogram represents the average liver parasite load in Leishman-Donovan units of Stauber (LDU = number of amastigotes / 1000 cell nuclei $\times$ organ weight in $\mathrm{mg}$ ) obtained at $30 \mathrm{DPI}$. Data are means \pm SE and represent the results of three independent experiments performed with 5-6 mice per treatment. Differences between groups are significant $*(p<0.05)$. 


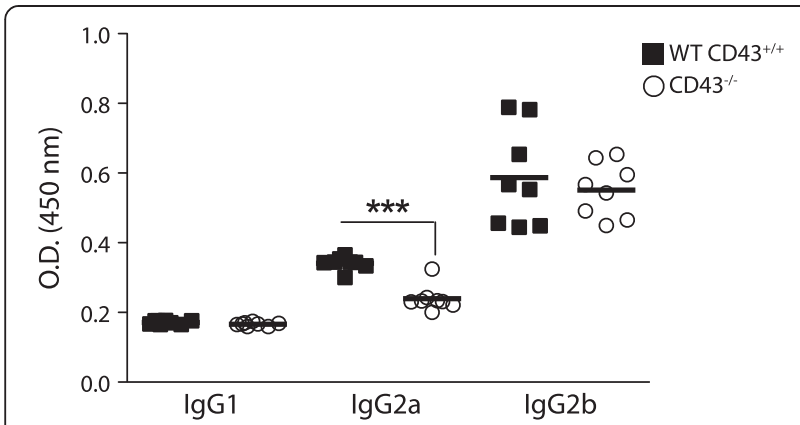

Figure 2 IgG profile of serum antibodies to Leishmania (L.) infantum chagasi of CD43-deficient mice. Sera of $\mathrm{CD}_{4} 3^{+/+}$and $\mathrm{CD}_{4} 3^{-1-}$ mice infected with $5 \times 10^{7}$ amastigote forms of Leishmania (L.) infantum chagasi were collected at $30 \mathrm{DPI}$ and the absorbance values of $\lg G$ antibody isotypes (lgG1, lgG2a and $\lg \mathrm{G} 2 \mathrm{~b}$ ) were determined by ELISA using Leishmania (L.) infantum chagasi promastigote lysates. Bars show levels of $\lg G 1, \lg G 2 a$ and $\lg G 2 b$ antibodies as the individual absorbancy values of 1/100 diluted sera. Asterisks indicate significant differences between groups ${ }^{* *}(p<0.001)$. Data represent the individual results for each group of mice of two independent experiments.

A major factor that is believed to contribute to healing in leishmaniasis is the development of a strong IFN- $\gamma$ response, which induces IgG2a production [23]. We therefore compared the cytokine responses to infection with Leishmania (L.) infantum chagasi parasites by analyzing the cytokines in supernatants of splenocytes isolated from infected wild-type and knockout mice stimulated with whole parasite antigens for 3 days. Splenocytes obtained from infected wild-type mice at 30 DPI when stimulated with parasite antigen mounted a typical protective proinflammatory response characterized by high levels of IFN- $\gamma$ and low levels of TGF- $\beta$ (Figure 3A, B). In contrast, the splenocytes from infected $\mathrm{CD} 43^{-/-}$mice produced reduced levels of IFN- $\gamma$ and high levels of TGF- $\beta$ upon stimulation with parasite antigens (Figure 3A, B). This clearly demonstrates that CD43-deficient mice have impaired immune response generation after infection with Leishmania (L.) infantum chagasi. In fact, splenocytes from $\mathrm{CD} 43^{-/-}$mice spontaneously secreted TGF- $\beta$ as seen in the unstimulated controls (Figure 3B) and did not decrease the production of IL-10 upon stimulation with parasite antigens as compared to wild-type cells (Figure 2C). We did not detect significant levels of TNF- $\alpha$ in the culture supernatants (Data not shown).

\section{The majority of intrahepatic $\mathrm{CD} 4^{+}$and $\mathrm{CD}^{+} \mathrm{T}$ cells with pro-inflammatory phenotypes express CD43 in visceral leishmaniasis}

We next examined whether the increased parasite load associated with absence of CD43 influenced the tissue distribution of intrahepatic $\mathrm{T}$ cells. It has been demonstrated that $\mathrm{T}$ cell- and lymphokine-dependent mechanisms are involved in the formation of antileishmanial tissue granulomas and the acquisition of resistance to Leishmania infection [22]. Hence we performed experiments to characterize the phenotypic distribution of intrahepatic $\mathrm{T}$ cells based on expression of the CD43 marker. In these experiments, wild-type mice were infected with amastigote forms of Leishmania (L.) infantum chagasi and the presence of $\mathrm{CD} 4^{+}$and $\mathrm{CD} 8^{+} \mathrm{T}$ cells in the spleen and liver was evaluated by FACS at 30 days postinfection. In both naïve and infected mice, the $\mathrm{CD} 43^{+}$subset in the $\mathrm{CD}_{4}^{+} \mathrm{T}$ cell compartment was significantly smaller than the $\mathrm{CD} 43^{-}$population whereas in the $\mathrm{CD} 8^{+}$ $\mathrm{T}$ cell compartment, the majority of cells expressed CD43 (Figure 4). A striking difference became apparent when we examined the expression of CD43 in the intrahepatic $\mathrm{CD} 4^{+} \mathrm{T}$ cell population during infection, as our data indicated that the majority of the $\mathrm{CD} 4^{+} \mathrm{T}$ cells, like the $\mathrm{CD}^{+} \mathrm{T}$ cells, were $\mathrm{CD} 43^{+}$(Figure 4 ).

Since the CD43 signaling pathway is involved in the Tbet-dependent expression of IFN- $\gamma$ by type- $1 \mathrm{~T}$ cells, we investigated the cytokine profiles of the $\mathrm{T}$ cell subsets based on the expression of the CD43 marker. Immunosuppression of antigen-specific immune responses due to impairment of DC activation, and $\mathrm{CD} 4^{+}$and $\mathrm{CD} 8^{+}$ $\mathrm{T}$ cell exhaustion has been demonstrated in visceral
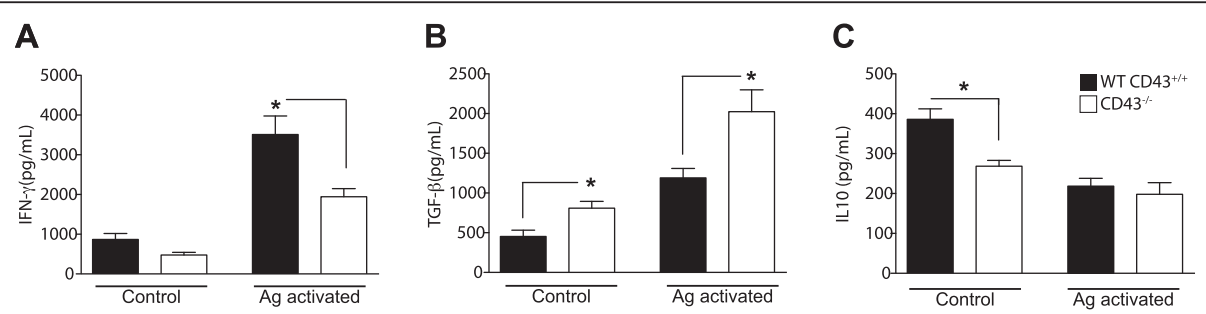

Figure 3 Splenocytes from CD43-deficient mice produce low levels of IFN- - . CD43 $3^{+/+}$and $C D 43^{-/-}$mice were infected intravenously with $5 \times 10^{7}$ amastigotes of Leishmania (L.) infantum chagasi, and 30 days after infection splenocytes were isolated and assayed for cytokine production. After 3 days of in vitro culture with freeze and thawed lysates of Leishmania (L.) infantum chagasi promastigotes, as described in the

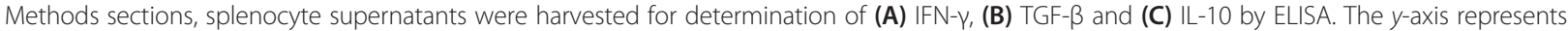
the levels of cytokines, detected by specific ELISA assays, expressed in $\mathrm{ng} / \mathrm{ml}$. Asterisks represent statistical significance between groups $(\mathrm{p}<0.05)$. All experiments were repeated at least 3 times. 


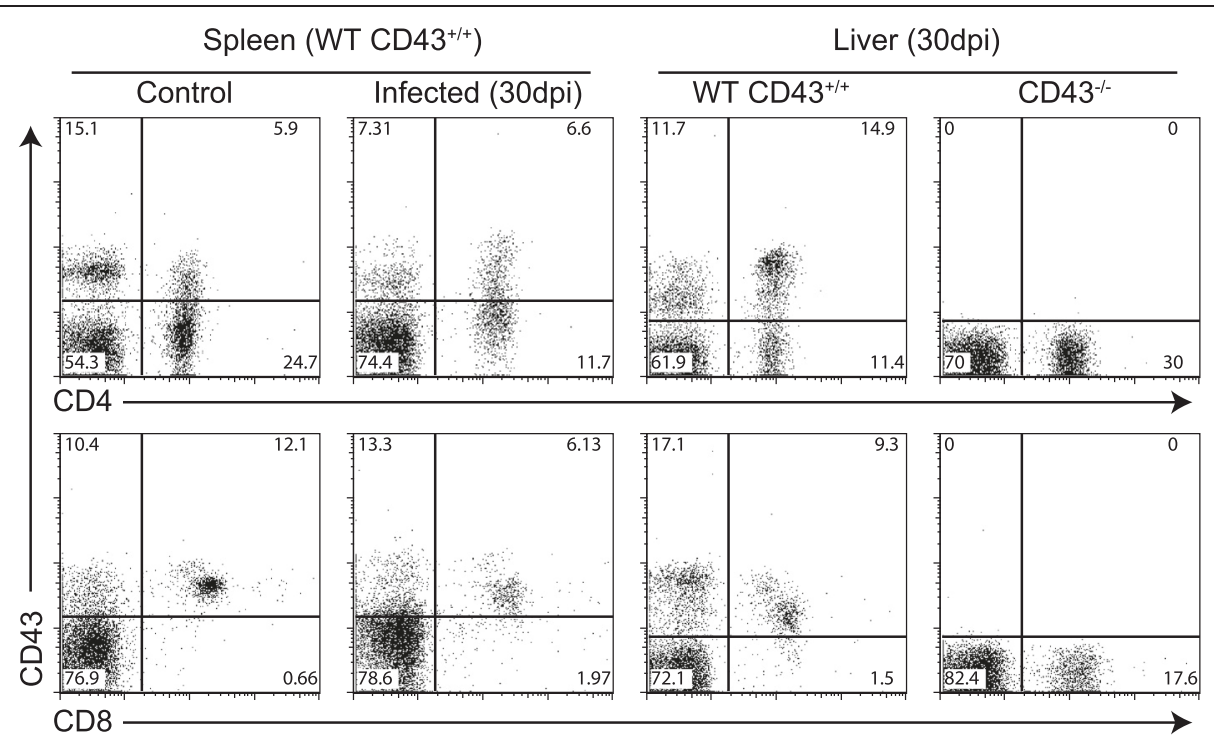

Figure 4 Expression of $\mathrm{CD}_{4} 3^{+} \mathrm{T}$ cells defines major intrahepatic $\mathrm{CD} 4^{+}$and $\mathrm{CD} 8^{+} \mathrm{T}$ cell subsets during visceral leishmaniasis. Following infection of $\mathrm{CD}_{4} 3^{+/+}$and $\mathrm{CD} 43^{-/-}$mice with $5 \times 10^{7}$ amastigotes of Leishmania (L.) infantum chagasi, spleens and livers were collected at $30 \mathrm{DPI}$ for FACS analysis. Splenocytes and mononuclear cells purified from livers were analyzed by FACS after staining with anti-CD43-FITC, anti-CD8-APC and anti-CD4-PE. Plots represent $\mathrm{CD} 43^{+} \mathrm{CD} 8^{+}$and $\mathrm{CD} 43^{+} \mathrm{CD} 4^{+}$lymphocyte pools derived from five mice. The values in the corners represent mean percentages of $\mathrm{CD}_{4} 3^{+}$cells in the total $\mathrm{CD} 4^{+}$or $\mathrm{CD} 8^{+} \mathrm{T}$ cell populations. Non-infected mice were used as controls. These data are representative of three independent experiments, using five mice per group.

leishmaniasis [24-26]. Indeed we found in our model that splenic T cells obtained from wild-type infected mice at 30 DPI secreted neither IFN- $\gamma$ nor TNF- $\alpha$ upon polyclonal stimulation with an anti-CD3 stimulus (Additional file 1: Figure S1). Therefore, in order to assess the polarization profiles of the intrahepatic $\mathrm{T}$ cell subsets during infection we measured changes in the levels of cytokine transcripts. Total RNA was isolated from $\mathrm{CD}_{4}^{+}$and $\mathrm{CD}^{+} \mathrm{T}$ cells sorted by FACS based on the expression of the CD43 marker and purified from the livers of wild-type mice at 30 days post-infection. Real-time RT-PCR analysis revealed a significantly higher level of induction of the proinflammatory cytokines IFN- $\gamma$ and TNF- $\alpha$ in the CD $43^{+}$ subset than in the $\mathrm{CD}_{4} 3^{-}$population (Figure 5). At the same time we detected a greater reduction of IL-17 and the regulatory TGF- $\beta$ and IL- 10 cytokines in the CD $43^{+} \mathrm{T}$ cell subsets, suggesting a role of $\mathrm{CD} 43^{+} \mathrm{T}$ cells in inflammatory responses during infection (Figure 5).

\section{Discussion}

The purpose of this study was to elucidate the role of CD43 in disease progression and immune responses in mice infected with Leishmania (L.) infantum chagasi. CD43 (leukosialin, sialophorin) is a large sialoglycoprotein that is abundantly expressed by cells of hemopoietic origin, including both $\mathrm{CD} 4^{+}$and $\mathrm{CD} 8^{+} \mathrm{T}$ cells [17]. Our experimental data clearly support a role for CD43 in the development of resistance to infection with Leishmania (L.) infantum chagasi, as our findings indicated that
$\mathrm{CD} 43^{-/-}$mice were defective in their DTH response to leishmanial antigens and had a higher hepatic parasite load.

It has been show in other systems that CD43 is able to affect the polarization of the Th immune response $[15,16,18,21]$. In the $M$. tuberculosis infection model, CD43 plays a role in the uptake of $M$. tuberculosis by macrophages and in type-1 immune responses $[27,28]$. Some mechanisms by which CD43 controls the intracellular growth of $M$. tuberculosis have been described. These include the induction of apoptosis and the production of reactive oxygen intermediates (ROI) and RNI, which are enhanced by cytokines such as IFN- $\gamma$ and TNF- $\alpha$ [29].

Although other studies have demonstrated a role of the CD43 signaling pathway in the innate defense of macrophages by increasing the oxidative burden during tuberculosis infection, we have ruled out this possibility in the case of Leishmania infection since macrophages derived from the bone marrow of $\mathrm{CD}_{4} 3^{+}$and $\mathrm{CD} 43^{-}$ mice were equally effective in eliminating Leishmania promastigotes (Additional file 2: Figure S2). However, our results show that protective immune responses elicited via CD43 are required for the increased expression of IFN- $\gamma$, which is associated with protective immune responses in this model and other murine models of infection with Leishmania parasites [30].

We further showed that the low levels of IFN- $\gamma$ in CD43-deficient mice infected with Leishmania (L.) 


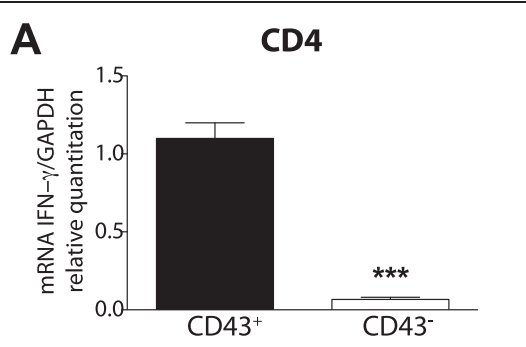

\section{B}

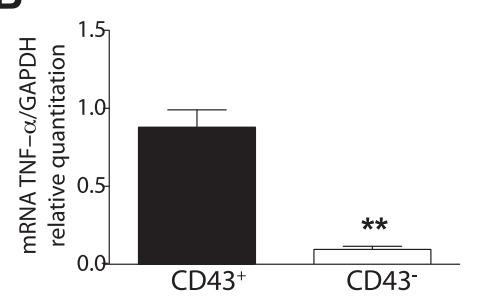

C

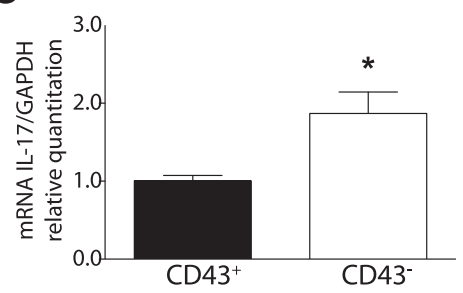

D

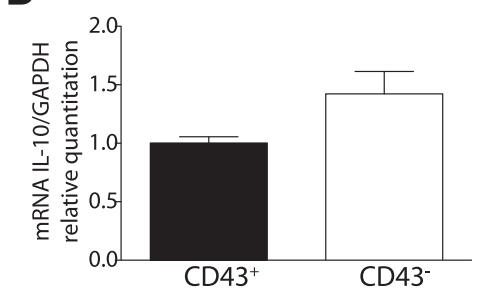

E

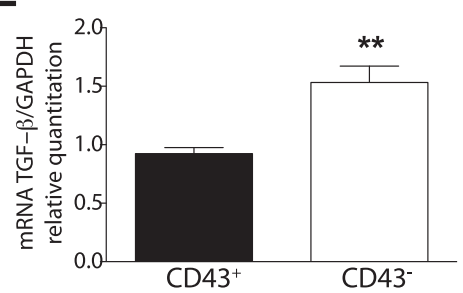

F CD8

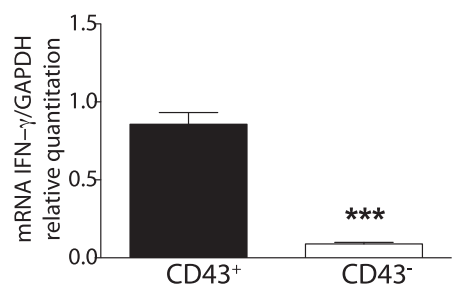

G



H

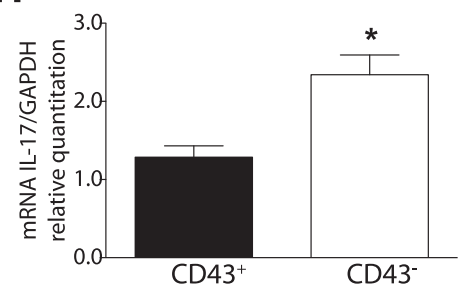

I

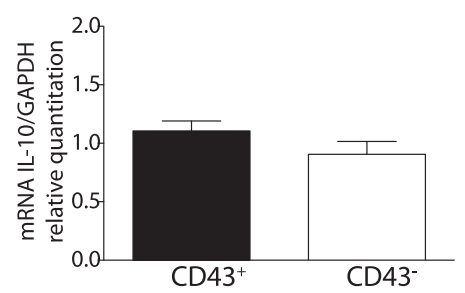

J

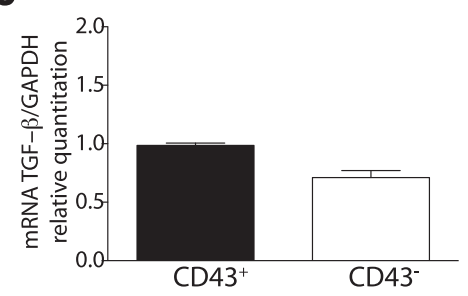

Figure 5 Intrahepatic $\mathrm{CD}_{3} 3^{+} \mathrm{CD} 4^{+}$and $\mathrm{CD}_{3} 3^{+} \mathrm{CD} 4^{+} \mathrm{T}$ cells exibit a pro-inflammatory phenotype in visceral leishmaniasis. Livers were removed from $\mathrm{CD}_{4} 3^{+/+}$wild-type mice infected with $5 \times 10^{7}$ amastigotes of Leishmania (L.) infantum chagasi at $30 \mathrm{DPI}$ and $\mathrm{CD} 43^{+} \mathrm{CD} 4^{+}$and $\mathrm{CD} 43$ ${ }^{+} \mathrm{CD} 8{ }^{+} \mathrm{T}$ cell subsets were purified by flow cytometry. To measure cytokine transcripts, total mRNA from highly purified (>98\%) T cell subsets (as indicated) were processed for RT-PCR. The results represent $(\mathbf{A}, \mathbf{F}) \mathrm{IFN}-\gamma$ transcripts, $(\mathbf{B}, \mathbf{G})$ TNF-a transcripts, $(\mathbf{C}, \mathbf{H}) \mathrm{IL}-17$ transcripts, $(\mathbf{D}, \mathbf{I}) \mathrm{IL}-10$ transcripts, and $(\mathbf{E}, \mathbf{J})$ TGF- $\beta$ transcripts, standardized with the housekeeping gene GAPDH, calculated as $2^{-\Delta C t}$ and presented as mean values \pm SE. All experiments were performed in triplicate and the data shown are representatives of three independent experiments using five mice per group. Indicated differences between groups are significant $*(p<0.05),{ }^{* *}(p<0.01),{ }^{* *}(p<0.001)$.

infantum chagasi were accompanied by increased production of the anti-inflammatory cytokine TGF- $\beta$ upon antigenic stimulation, so resulting in a decreased ratio of IFN- $\gamma /$ TGF- $\beta$ compared with wild-type infected mice. This alteration could lead to macrophage dysfunction in vivo as it has been shown that increased levels of
TGF- $\beta$ promote parasite replication inside macrophages [11]. Beside of its effect on macrophage activation, IFN$\gamma$ stimulates B lymphocytes to produce IgG2a, which plays a critical role in resistance to leishmaniasis by activating macrophage defenses through increasing parasite uptake and anti-parasite activity [23]. 
It is of interest that infection of CD43-deficient mice results in reduced levels of IgG2a implying that the type1 response to infection is compromised. Our findings pointed to a critical role of the CD43 on the acquisition of host protective responses, as we observed striking differences in the liver parasite burdens under infection with Leishmania (L.) infantum chagasi indicating a less efficient control of the parasite replication in CD43-deficient mice during infection. It has been shown that besides its role as a regulator of immunity, the CD43 signaling pathway participates in the migration and tissue distribution of circulating leukocytes to secondary lymphoid organs and peripheral tissues $[16,19,20]$.

We have also observed an altered distribution of CD $43^{+}$ $\mathrm{T}$ cells in the periphery, as experimental infection of wild-type mice with Leishmania (L.) infantum chagasi yielded an increased proportion of intrahepatic $\mathrm{CD} 43^{+} \mathrm{T}$ cells, in both $\mathrm{CD}^{+}$and $\mathrm{CD} 8^{+}$subsets, with an effector profile based on the expression of the major proinflammatory cytokines associated with hepatic control of parasite load during the acute phase of infection [22]. Our results indicated that the weakened control of the intrahepatic parasite load was correlated with loss of the majority of $\mathrm{CD}_{4} 3^{+} \mathrm{CD}^{+}$and $\mathrm{CD} 8^{+} \mathrm{T}$ cells exhibiting pro-inflammatory cytokine profiles. In fact, in visceral leishmaniasis, the acquisition of intrahepatic resistance to the parasite is a consequence of the tissue expression of a protective $\mathrm{T}$ cell response that promotes the attraction of competent cells to potentiate the anti-microbial activity of infected Kupffer cells by inducing the production of reactive oxygen and nitrogen intermediates as well as the pro-inflammatory cytokines IFN- $\gamma$ and TNF$\alpha$, which play a critical role in liver granuloma formation and control of parasite colonization [22].

\section{Conclusions}

Together our data define, for the first time, a role for CD43 in the hepatic protective immune response against parasite reservoirs in visceral leishmaniasis. We observed that $\mathrm{CD} 43^{-1-}$ mice were more susceptible to the disease, which implies that sialoprotein participates in disease resolution and elimination of the parasite. More specifically we demonstrated that loss of CD43 signaling pathway resulted in a modulation of the cytokine balance, with a significant decrease in the IFN- $\gamma$ type 1 response, which is essential for elimination of the parasite. A successful immune response is also correlated with the diminished production of the anti-inflammatory cytokine, TGF- $\beta$, which promotes susceptibility to the disease. Understanding how host protective immune responses can affect the intracellular growth of Leishmania parasites could lead to the development of novel therapeutic or preventative measures against this devastating pathogen.

\section{Additional files}

Additional file 1: Figure S1. Flow cytometric analysis of intracellula IFN- $\gamma$ in T cells from visceral leishmaniasis. Spleens from $\mathrm{CD}_{4} 3^{+/+}$wild-type mice were collected on day 30 after infection with $5 \times 10^{7}$ amastigotes of $L$. (L) infantum chagasi to assay intracellular expression for IFN- $\gamma$. Splenocytes were stimulated with plate-bound anti-CD3 $(5 \mu \mathrm{g} / \mathrm{mL})$, in the presence of GolgiPlug (brefeldin A) for $6 \mathrm{~h}$ at $37^{\circ} \mathrm{C}$ in $5 \% \mathrm{CO}_{2}$. Samples were stained with CD3-FITC, CD4-Cy-Chrome (A) and CD8-APC (B) and then intracellularly with IFN- $\gamma$ PE as described in Methods. Results are representative of duplicate cultures from three different experiments.

Additional file 2: Figure S2. Bone marrow-derived macrophages from $\mathrm{CD}_{4} 3^{-/}$and wild-type cells have similar levels of infectivity with Leishmania (L.) chagasi promastigotes. Bone marrow-derived macrophages generated from $\mathrm{CD}_{4} 3^{+/+}$and $\mathrm{CD}_{4} 3^{-/}$mice were infected with amastigotes at a 10:1 ratio of parasites: host cells. At 1 hour after infection, cells were washed to determine the \% infection, and the cultures were incubated for a further 72 hours to measure intracellular growth of the amastigote forms. The number of intracellular parasites per 100 cell nuclei was determined after citospinning the cells onto glass slides, followed by fixation and Giemsa staining. Data represent the mean \pm SEM of triplicate assays and are representative of two independent experiments.

\section{Competing interests}

The authors declare that they have no competing interests.

\section{Authors' contributions}

Conceived and designed the experiments: AM. Performed the experiments: DN, NM, LS, ES. Analyzed the data: DN, ES, AMV, AM. Contributed reagents/ materials/analysis tools: JLPC, NRM, CGFL, AT, JCFR, CBPS, AM. Wrote the paper: AM. All authors read and approved the final version of the manuscript.

\section{Acknowledgments}

This work was supported by grants from Conselho Nacional de Desenvolvimento Científico e Tecnológico do Brasil (CNPq), Fundação de Amparo à Pesquisa do Estado do Rio de Janeiro (FAPERJ).

\section{Author details}

'Departamento de Microbiologia Geral, Instituto de Microbiologia, Universidade Federal do Rio de Janeiro, Rio de Janeiro, Brazil. ²Departamento de Imunologia, Instituto de Microbiologia, Universidade Federal do Rio de Janeiro (UFRJ), CCS Sala D1-035, Av. Carlos Chagas Filho, 373 - Cidade Universitária, CEP 21.941-902, Itha do Fundão, Rio de Janeiro, RJ, Brazil. ${ }^{3}$ Instituto de Biofísica Carlos Chagas Filho, Universidade Federal do Rio de Janeiro, Rio de Janeiro, Brazil.

Received: 24 November 2014 Accepted: 6 February 2015 Published online: 19 February 2015

\section{References}

1. Kaye P, Scott P. Leishmaniasis: complexity at the host-pathogen interface. Nat Rev Microbiol. 2011;9(8):604-15

2. McCall LI, Zhang WW, Matlashewski G. Determinants for the development of visceral leishmaniasis disease. PLoS Pathog. 2013;9(1):e1003053.

3. Wilson ME, Sandor M, Blum AM, Young BM, Metwali A, Elliott D, et al. Local suppression of IFN-gamma in hepatic granulomas correlates with tissuespecific replication of Leishmania chagasi. J Immunol. 1996;156(6):2231-9.

4. Kumar R, Nylén S. Immunobiology of visceral leishmaniasis. Front Immunol. 2012;14;3:251.

5. Afonso LC, Scharton TM, Vieira LQ, Wysocka M, Trinchieri G, Scott P. The adjuvant effect of interleukin-12 in a vaccine against Leishmania major. Science. 1994;14;263(5144):235-7.

6. Walker PS, Scharton-Kersten T, Krieg AM, Love-Homan L, Rowton ED, Udey MC, et al. Immunostimulatory oligodeoxynucleotides promote protective immunity and provide systemic therapy for leishmaniasis via IL-12- and IFN-gamma-dependent mechanisms. Proc Natl Acad Sci U S A. 1999;8;96(12):6970-5.

7. Liew FY, Parkinson C, Millott S, Severn A, Carrier M. Tumour necrosis factor (TNF alpha) in leishmaniasis. I TNF alpha mediates hostprotection against cutaneous leishmaniasis Immunology. 1990;69(4):570-3. 
8. Bucheton B, Abel L, Kheir MM, Mirgani A, El-Safi SH, Chevillard C, et al. Genetic control of visceral leishmaniasis in a Sudanese population: candidate gene testing indicates a linkage to the NRAMP1 region. Genes Immun. 2003;4(2):104-9.

9. Moll $H$, Röllinghoff $M$. Resistance to murine cutaneous leishmaniasis is mediated by $\mathrm{TH} 1$ cells, butdisease-promoting CD4+ cells are different from TH2 cells. Eur J Immunol. 1990;20(9):2067-74.

10. Ansel KM, Greenwald RJ, Agarwal S, Bassing CH, Monticelli S, Interlandi J, et al. Deletion of a conserved II4 silencer impairs T helper type 1-mediated immunity. Nat Immunol. 2004;5(12):1251-9. Epub 2004 Oct 31.

11. Li J, Hunter CA, Farrell JP. Anti-TGF-beta treatment promotes rapid healing of Leishmania major infection in mice by enhancing in vivo nitric oxide production. J Immunol. 1999;162(2):974-9.

12. Mehrotra S, Fakiola M, Oommen J, Jamieson SE, Mishra A, Sudarshan M, et al. Genetic and functional evaluation of the role of CXCR1 and CXCR2 in susceptibility to visceral leishmaniasis in north-east India. BMC Med Genet. 2011;12:162.

13. Mehrotra S, Fakiola M, Mishra A, Sudarshan M, Tiwary P, Rani DS, et al. Genetic and functional evaluation of the role of DLL1 in susceptibility to visceral leishmaniasis in India. Infect Genet Evol. 2012;12(6):1195-201.

14. Murray HW, Lu CM, Brooks EB, Fichtl RE, DeVecchio JL, Heinzel FP. Modulation of T-cell costimulation as immunotherapy or immunochemotherapy in experimental visceral leishmaniasis. Infect Immun. 2003;71(11):6453-62.

15. Ford ML, Onami TM, Sperling Al, Ahmed R, Evavold BD. CD43 modulates severity and onset of experimental autoimmuneencephalomyelitis. J Immunol. 2003;171(12):6527-33.

16. Johnson GG, Mikulowska A, Butcher EC, McEvoy LM, Michie SA. Anti-CD43 monoclonal antibody L11 blocks migration of T cells to inflamed pancreatic islets and prevents development of diabetes in nonobese diabetic mice. J Immunol. 1999;163(10):5678-85.

17. Clark MC, Baum LG. T cells modulate glycans on CD43 and CD45 during development and activation, signal regulation, and survival. Ann N Y Acad Sci. 2012;1253:58-67.

18. Ramírez-Pliego O, Escobar-Zárate DL, Rivera-Martínez GM, Cervantes-Badillo MG, Esquivel-Guadarrama FR, Rosas-Salgado G, et al. CD43 signals induce type one lineage commitment of human CD4+ T cells. BMC Immunol. 2007:8:30.

19. McEvoy LM, Sun H, Frelinger JG, Butcher EC. Anti-CD43 inhibition of T cell homing. J Exp Med. 1997;185(8):1493-8.

20. Woodman RC, Johnston B, Hickey MJ, Teoh D, Reinhardt P, Poon BY, et al. The functional paradox of CD43 in leukocyte recruitment: a study using CD43-deficient mice. J Exp Med. 1988;188(11):2181-6.

21. Onami TM, Harrington LE, Williams MA, Galvan M, Larsen CP, Pearson TC, et al. Dynamic regulation of T cell immunity by CD43. J Immunol. 2002;168(12):6022-31.

22. Moore JW, Moyo D, Beattie L, Andrews PS, Timmis J, Kaye PM. Functional complexity of the Leishmania granuloma and the potential of in silico modeling. Front Immunol. 2013:4:35.

23. Selvapandiyan A, Dey R, Nylen S, Duncan R, Sacks D, Nakhasi HL. Intracellular replication-deficient Leishmania donovani induces long lasting protective immunity against visceralleishmaniasis. J Immunol. 2009;183(3):1813-20.

24. Ato M, Stäger S, Engwerda CR, Kaye PM. Defective CCR7 expression on dendritic cells contributes to the development of visceral leishmaniasis. Nat Immunol. 2002;3(12):1185-91. Epub 2002 Nov 18.

25. Esch KJ, Juelsgaard R, Martinez PA, Jones DE, Petersen CA. Programmed death 1-mediated T cell exhaustion during visceral leishmaniasis impairs phagocyte function. J Immunol. 2013;191(11):5542-50.

26. Gautam S, Kumar R, Singh N, Singh AK, Rai M, Sacks M, et al. CD8 T cell exhaustion in human visceral leishmaniasis. J Infec Dis. 2014;209(2):290-9.

27. Fratazzi C, Manjunath N, Arbeit RD, Carini C, Gerken TA, Ardman B, et al. A macrophage invasion mechanism for mycobacteria implicating the extracellular domain of CD43. J Exp Med. 2000;192(2):183-92.

28. Randhawa AK, Ziltener HJ, Merzaban JS, Stokes RW. CD43 is required for optimal growth inhibition of Mycobacterium tuberculosis in macrophages and in mice. J Immunol. 2005;175(3):1805-12.

29. Randhawa AK, Ziltener HJ, Stokes RW. CD43 controls the intracellular growth of Mycobacterium tuberculosis through the induction of TNF-alphamediated apoptosis. Cell Microbiol. 2008;10(10):2105-17.

30. Swihart K, Fruth U, Messmer N, Hug K, Behin R, Huang S, et al. Mice from a genetically resistant background lacking the interferon gamma receptor are susceptible to infection with Leishmania major but mount a polarized T helper cell 1-type CD4+ T cell response. J Exp Med. 1995;181(3):961-71.

\section{Submit your next manuscript to BioMed Central and take full advantage of:}

- Convenient online submission

- Thorough peer review

- No space constraints or color figure charges

- Immediate publication on acceptance

- Inclusion in PubMed, CAS, Scopus and Google Scholar

- Research which is freely available for redistribution

Submit your manuscript at www.biomedcentral.com/submit 